\title{
Relationships between leucine and the pancreatic exocrine function for improving starch digestibility in ruminants
}

\author{
K. Liu, ${ }^{*}$ Y. Liu, ${ }^{*}$ S. M. Liu,† M. Xu,‡ Z. P. Yu, ${ }^{*}$ X. Wang, ${ }^{*}$ Y. C. Cao, ${ }^{\star}$ and J. H. Yao* \\ ${ }^{*}$ College of Animal Science and Technology, Northwest A\&F University, Yangling Shaanxi, China, 712100 \\ †Institute of Agriculture, University of Western Australia, Crawley, WA 6009, Australia \\ $\ddagger$ College of Animal Science and Medicine, Inner Mongolia Agricultural University, Hohhot, Inner Mongolia, China, 01008
}

\section{ABSTRACT}

Four Holstein heifers $(215 \pm 7 \mathrm{~kg}$; means $\pm \mathrm{SD})$, fitted with one pancreatic pouch, duodenal re-entrant cannulas, and duodenal infusion catheters, were used in this experiment. In phase 1 , the 24 -h profile of pancreatic fluid was determined. Pancreatic fluid flow peaked $1 \mathrm{~h}$ after feeding, but peaks of similar magnitude also occurred before the morning feed, necessitating 24-h collection of pancreatic fluid to estimate daily excretion. In phase 2 , the effects of duodenal infusions of $0,10,20$, or $30 \mathrm{~g}$ of leucine on pancreatic fluid flow were determined in a $4 \times 4$ Latin square design. The leucine was infused for $12 \mathrm{~h}$ in $2,500 \mathrm{~mL}$ of the infusate, and samples of pancreatic fluid and jugular blood were collected in 1-h intervals from the beginning of the infusion for $36 \mathrm{~h}$. The results showed that the secretion rate of pancreatic fluid $(\mathrm{mL} / \mathrm{h})$ was significantly higher in 10-g leucine group than the other groups $(\mathrm{mL} / \mathrm{h})$. Protein concentration $(\mathrm{mg} / \mathrm{mL})$ in pancreatic fluid was elevated proportional to the amount of leucine infused. Leucine infusions increased both the concentration (U/ $\mathrm{mL})$ and secretion rate $(\mathrm{U} / \mathrm{h})$ of $\alpha$-amylase. Infusion of $10 \mathrm{~g}$ of leucine also increased the secretion rates $(\mathrm{U} / \mathrm{h})$ of trypsin, chymotrypsin, and lipase, but did not change their concentrations. No significant effects of leucine infusions on plasma glucose and insulin concentrations were found. The results indicate that leucine could act as a nutrient signal to stimulate $\alpha$-amylase production and pancreatic exocrine function in dairy heifers.

Key words: amino acid, duodenal infusion, digestive enzyme, insulin, cow

\section{INTRODUCTION}

Starch is a major component in concentrate feedstuffs, providing a substantial energy source to highly

Received May 26, 2014.

Accepted December 21, 2014.

${ }^{1}$ Corresponding author: yaojunhu2004@sohu.com productive ruminants. Starch is mainly degraded by the rumen fauna and flora, but starch also has a considerable capacity to be digested in the small intestine. Reynolds (2006) suggested that starch digestion averages $695 \mathrm{~g} / \mathrm{kg}$ of duodenal starch appearance in the small intestine. However, the capacity may be limited; for example, Matthé et al. (2001), in a summary of published data from nonlactating cattle, concluded that with increasing starch flow to the small intestine (from 250 to $1,800 \mathrm{~g} / \mathrm{d}$ ), starch digestibility in the small intestine decreased from 800 to $500 \mathrm{~g} / \mathrm{kg}$, respectively. When the capacity for starch digestion is limited, the part of starch reaching the small intestine that is digested before the ileal-cecal junction may decrease, and undigested starch is then fermented in the hindgut, resulting in energy waste and health risks (Gressley et al., 2011). Many factors limit starch digestion in the small intestine, among them, a lack of pancreatic $\alpha$-amylase. Harmon et al. (2004) found that increasing $\alpha$-amylase secretion might be a way to improve postruminal starch digestion in cattle.

Leucine is one of the essential amino acids for mammals as a substrate for protein synthesis and is considered an efficient nutrient signal regulating protein synthesis (Suryawan et al., 2011). Leucine, either administrated orally or injected, increases protein synthesis in skeletal muscle, liver, heart, pancreas, and other tissues (Escobar et al., 2005; Yin et al., 2010; Wilson et al., 2011). However, Hashimoto and Hara (2004) found that leucine reduces the expression and activity of pancreatic $\alpha$-amylase in rats. Thus, the role of leucine in protein synthesis is still not clear (Proud, 2007), and little information is available on the effect of leucine on digestive enzymes in ruminants. Rulquin and Pisulewski (2006) showed that a duodenal infusion of leucine affected milk protein yield in a curvilinear manner, with milk protein yield reaching a peak value of $82 \mathrm{~g} / \mathrm{d}$ at an infusion rate of $40 \mathrm{~g} / \mathrm{d}$; then, protein yield was depressed at higher rates of infusion. This paper addresses the hypothesis that leucine administration influences pancreatic flow and alters the secretion of pancreatic enzymes in Holstein heifers. 


\section{MATERIALS AND METHODS}

The use of the animals and experimental protocols was approved by the Animal Care and Use Committee of the College of Animal Science and Technology of the Northwest A\&F University, China.

\section{Animals and Surgery}

Four Chinese Holstein heifers $(215 \pm 7 \mathrm{~kg}$; mean \pm SD) were surgically prepared with a pancreatic pouch into which the main pancreatic duct drains, and 2 duodenal cannulas. Surgical procedures used were as described by St. Jean et al. (1992) with some modifications as follows.

General anesthesia was induced with a mixture of cyclopropane, methoxyflurane, and isoflurane. A 150 to $200 \mathrm{~mm}$ incision was made over the last rib and 8 $\mathrm{cm}$ from the lumbar vertebral transverse process, and extended down the rib to the costro-chondral junction. The periosteum was stripped and a segment of the last rib was removed, and the incision deepened into the abdominal cavity. The anatomical relationships between the duodenum, liver, and pancreas were explored by blunt dissection and the cranial lobe of the pancreas with pancreatic duct was located.

Pancreatic fluid was collected by placing a cannula into a 40 to $60 \mathrm{~mm}$ pouch of the duodenum into which the main pancreatic duct drained. The duodenal pouch was formed by clamping the duodenum 30 to $40 \mathrm{~mm}$ anterior and posterior to the pancreatic duct opening. One end of the segment was closed by oversewing the clamp, and a T-shaped cannula was inserted from the other end and pulled through a small incision in the duodenal pouch, which was opposite to the duct opening within the intestine canal. The other end of the pouch was closed, and both ends of the duodenal pouch were secured with a purse-string suture. The continuity of the intestine was restored by an end-to-end anastomosis.

After the cannulated pouch had been formed, another 2 cannulas were inserted into the duodenum, one $10 \mathrm{~cm}$ from the pylorus for infusions and the other with 10 to $15 \mathrm{~cm}$ posterior to the anastomosis for the return of pancreatic fluid. All 3 cannulas were exteriorized through small incisions in the abdomen wall, and the abdominal cavity was closed.

\section{Diets}

Heifers were fed at $1.2 \times \mathrm{NE}_{\mathrm{M}}$ requirement for cattle (NRC, 1996) on an alfalfa hay-based diet plus a supplement (Tables 1 and 2). Feed offered was adjusted on a BW basis for each period. The daily feed allowance was
Table 1. Composition and nutrient levels of experimental diets (DM basis)

\begin{tabular}{lc}
\hline Item & Content \\
\hline Ingredient, \% & \\
Alfalfa hay & 80.0 \\
Concentrate & 20.0 \\
Total & 100.0 \\
Nutrient level & \\
CP, \% & 12.57 \\
MCP, ${ }^{1} \%$ & 9.4 \\
ME, ${ }^{M J} / \mathrm{kg}$ & 9.62 \\
Ca, \% & 0.92 \\
P, \% & 0.33 \\
Ash, \% & 5.65 \\
Alfalfa hay composition, \% of DM & \\
DM & 86.16 \\
OM & 90.48 \\
CP & 11.97 \\
NDF & 55.13 \\
ADF & 40.07 \\
\hline
\end{tabular}

${ }^{1} \mathrm{MCP}=$ metabolizable protein. The values of MCP and ME were estimated based on NRC (1996).

divided into 4 equal portions and fed at 0800, 1200, 1600 , and $2000 \mathrm{~h}$, respectively, and orts were removed daily before the $0800 \mathrm{~h}$ feeding. Heifers were housed in individual pens $(3 \mathrm{~m} \times 3 \mathrm{~m})$ at a constant ambient temperature of $20^{\circ} \mathrm{C}$ with daily length of $16 \mathrm{~h}$. Fresh water was supplied ad libitum.

\section{Phase 1}

Pancreatic fluid flow was measured continuously over a 7 -d period at hourly intervals. The volume of the pancreatic fluid was measured, and the fluid was returned to the duodenum. The substantial variations

Table 2. Ingredients and nutrient contents of the concentrate supplement (DM basis)

\begin{tabular}{lr}
\hline Item & Value \\
\hline Ingredient, \% of DM & \\
Corn & 70.00 \\
DDGS & 5.00 \\
Corn germ feed & 19.00 \\
Limestone $_{\text {CaHPO }}$ & 1.40 \\
Maltose $_{\text {NaHCO }}$ & 1.00 \\
Salt & 0.60 \\
Mineral and vitamin premix & 1.00 \\
Nutrient content, & ${ }^{1} \%$ \\
CP & 1.00 \\
Ca & 1.00 \\
P & 18.01 \\
Ash & 1.17 \\
\hline One & 0.55 \\
\hline
\end{tabular}

${ }^{1}$ One kilogram of the premix contains $50 \mathrm{mg}$ of $\mathrm{Mn}, 50 \mathrm{mg}$ of $\mathrm{Zn}, 10$ $\mathrm{mg}$ of $\mathrm{Cu}, 0.5 \mathrm{mg}$ of I, $0.2 \mathrm{mg}$ of Se, $2,200 \mathrm{IU}$ of vitamin A, $275 \mathrm{IU}$ of vitamin D, $25 \mathrm{IU}$ of vitamin $\mathrm{E}$, and $2,000 \mathrm{mg}$ of nicotinic acid.

${ }^{2}$ Based on analyses of the samples. 
in the fluid volume with multiple pulse patterns were observed, which necessitated continuous collections of the pancreatic fluid for $24 \mathrm{~h}$ to accurately represent daily pancreatic secretion. The heifers were then allowed to recover to the initial state for $7 \mathrm{~d}$ before the next infusion experiment.

\section{Phase 2}

The heifers were randomly assigned to a $4 \times 4$ Latin square design to determine the effects of duodenal infusion of leucine on pancreatic function. Infusions started at $0700 \mathrm{~h}$ using a peristaltic pump at the rate of 208 $\mathrm{mL} / \mathrm{h}$ for $12 \mathrm{~h}$. The infusate was either $0,10,20$, or 30 $\mathrm{g}$ leucine dissolved in $2,500 \mathrm{~mL}$ of water, where $20 \mathrm{~g}$ was similar to the dose used by Rulquin and Pisulewski (2006).

The pancreatic fluid was continuously collected at hourly intervals for $12 \mathrm{~h}$ from the beginning of the infusion. The volume and $\mathrm{pH}$ of the fluid were recorded, and a $10 \%$ sub-sample was collected and stored at $-30^{\circ} \mathrm{C}$ until analysis. The remaining fluid was returned into the duodenum. At the completion of the sampling period, the heifers were allowed a 7 -d rest period to allow the cattle to return to a stable basal body state.

During the infusion and pancreatic collection period, blood samples $(10 \mathrm{~mL}$ each) were collected hourly by jugular puncture into a heparinized syringe, immediately centrifuged at $2,500 \times g$ for $15 \mathrm{~min}$ at $4^{\circ} \mathrm{C}$, and then plasma was collected and stored at $-80^{\circ} \mathrm{C}$ until analysis.

\section{Sample Analysis}

Pancreatic fluid samples were analyzed for total protein concentration (Smith et al., 1985) and activities of $\alpha$-amylase (Walker and Harmon, 1996), trypsin (Geiger and Fritz, 1986), and lipase (Xu et al., 2009). One unit of enzyme activity was defined as $1 \mu \mathrm{mol}$ of the product released per minute at $39^{\circ} \mathrm{C}$. Plasma insulin concentrations were measured using a commercial kit (Beijing North Institute of Biological Technology, Beijing, China).

\section{Data Calculation and Statistical Analysis}

In phase 1 , the means and standard deviations of pancreatic fluid flow rate from the 4 heifers over $7 \mathrm{~d}$ were calculated for each sampling times.

In phase 2 , the means of 12 measures, unless otherwise specified, were calculated, and then used for statistical analysis. Data were analyzed as a $4 \times 4$ Latin square design using the general linear model procedure of SAS (SAS Inst. Inc., Cary, NC) to examine effects of treatments, animals, and periods. When the effect of treatment was significant $(P<0.05)$, the comparison was made between the means using Student's $t$-test. Differences were considered significant at $P<0.05$.

\section{RESULTS}

\section{Phase 1}

Phase 1 was undertaken to determine daily patterns of pancreatic fluid secretion in heifers fed 4 times per day. The secretion of pancreatic fluid showed a multiple pulse pattern, and was stimulated an hour after feeding (Figure 1). Peak pancreatic flow decreased linearly until the early hours of the morning.

\section{Phase 2}

The secretion rate $(\mathrm{mL} / \mathrm{h})$ of pancreatic fluid was significantly increased by an infusion of $10 \mathrm{~g}$ of leucine $(P=0.008)$, whereas no significant differences were found between the control and 20 or $30 \mathrm{~g}$ leucine infusions (Table 3). Infusions of leucine had no influence on $\mathrm{pH}$ of pancreatic fluid $(P>0.05)$. Protein concentration $(\mathrm{mg} / \mathrm{mL})$ in pancreatic fluid was elevated $(P=$ 0.044) proportional to the amount of leucine infused, and protein secretion rate $(\mathrm{mg} / \mathrm{h})$ was increased $(P=$ 0.024 ) by leucine infusions, with the peak value for 10 $\mathrm{g}$ of leucine due to its highest flow rate of pancreatic fluid (Table 3).

As shown in Table 4, both the concentration $(\mathrm{U} / \mathrm{mL})$ and secretion rate $(\mathrm{U} / \mathrm{h})$ of $\alpha$-amylase were increased by infusions of 10,20 , and $30 \mathrm{~g}$ of leucine $(P=0.050$ and 0.007 respectively). For trypsin, infusion of $10 \mathrm{~g}$ of leucine increased the secretion rate $(\mathrm{U} / \mathrm{h} ; P=0.018)$, but not the concentration $(\mathrm{U} / \mathrm{L})$. The secretion rate $(\mathrm{U} / \mathrm{h})$ of chymotrypsin was increased by infusions of 10 and $30 \mathrm{~g}$ of leucine $(P=0.037)$, but the concentration $(\mathrm{U} / \mathrm{L})$ of chymotrypsin was not affected $(P>0.05)$. The secretion rate $(\mathrm{U} / \mathrm{L})$ of lipase was increased by infusions of 10 and $20 \mathrm{~g}$ of leucine $(P<0.001)$ with no effect on lipase concentration $(P>0.05)$ (Table 4$)$.

Infusions of leucine had no influence on plasma glucose concentration $(P>0.05)$, whereas an increased tendency was found for insulin concentration $(P=$ 0.091; Table 5).

\section{DISCUSSION}

Diurnal pancreatic secretions in heifers were pulsatory with multiple pulses over $24 \mathrm{~h}$ and responding to feeding. Therefore, extended periods for collection of pancreatic fluid are essential to obtain representative samples of studies on pancreatic functions (Xu et 
Table 3. Effects of duodenal infusion of leucine on the secretion rate, $\mathrm{pH}$, and protein concentration of pancreatic fluid

\begin{tabular}{|c|c|c|c|c|c|c|}
\hline \multirow[b]{2}{*}{ Item } & \multicolumn{4}{|c|}{ Leucine infusion, $g$} & \multirow[b]{2}{*}{$\mathrm{SEM}^{1}$} & \multirow[b]{2}{*}{$P$-value } \\
\hline & 0 & 10 & 20 & 30 & & \\
\hline Secretion, $\mathrm{mL} / \mathrm{h}$ & $122.3^{\mathrm{b}}$ & $175.2^{\mathrm{a}}$ & $131.1^{\mathrm{b}}$ & $128.4^{\mathrm{b}}$ & 7.74 & 0.008 \\
\hline $\mathrm{pH}$ & 7.21 & 7.22 & 7.05 & 7.25 & 0.032 & 0.275 \\
\hline $\begin{array}{l}\text { Protein } \\
\mathrm{mg} / \mathrm{mL} \\
\mathrm{mg} / \mathrm{h}\end{array}$ & $\begin{array}{r}6.03^{\mathrm{c}} \\
738^{\mathrm{c}}\end{array}$ & $1,214^{\mathrm{a}} \mathrm{3}^{\mathrm{bc}}$ & $1,024^{7.81^{\mathrm{ab}}}$ & $1,096^{\mathrm{b}}$ & $\begin{array}{l}0.351 \\
61.3\end{array}$ & $\begin{array}{l}0.044 \\
0.024\end{array}$ \\
\hline
\end{tabular}

${ }^{\mathrm{a}-\mathrm{c}}$ Means within a row with different superscripts differ $(P \leq 0.05)$.

${ }^{1}$ Pooled standard error of the means, $\mathrm{n}=4$.

al., 2009). In phase 1, pancreatic secretion (Figure 1) increased significantly after each feeding, which is supported by previous reports (McCormick and Stewart, 1967; Xu et al., 2009). The reason may be related to the intermittent feeding and the resultant outflow to the small intestine (Xu et al., 2006). In contrary to our results, pancreatic fluid secretion had little or no postprandial fluctuation in sheep (Shimomura et al., 2004, 2006). Similar results were also observed in steers fed 12 times a day (Walker and Harmon, 1995). Pancreatic fluid plays an important role in buffering and maintaining optimum conditions for the activities of pancreatic enzymes in the small intestine for nutrient digestion, and any increase in secretion of pancreatic fluid may result in more efficient digestion of nutrients.

The duodenal infusion of $10 \mathrm{~g}$ of leucine significantly increased the pancreatic fluid secretion in this experiment. The secretion rate of pancreatic fluid, when expressed per unit of BW, ranged from 0.55 to 0.61 $\mathrm{mL} \cdot \mathrm{kg}^{-1} \cdot \mathrm{h}^{-1}$, except for $0.81 \mathrm{~mL} \cdot \mathrm{kg}^{-1} \cdot \mathrm{h}^{-1}$ for the $10 \mathrm{~g}$ of leucine group, in the current experiment, similar to previous reports $\left(0.23\right.$ to $0.60 \mathrm{~mL} \cdot \mathrm{kg}^{-1} \cdot \mathrm{h}^{-1}$; Swanson et al., 2002, 2004; Richards et al., 2003). Previous studies in our laboratory showed that infusions of 3 ,

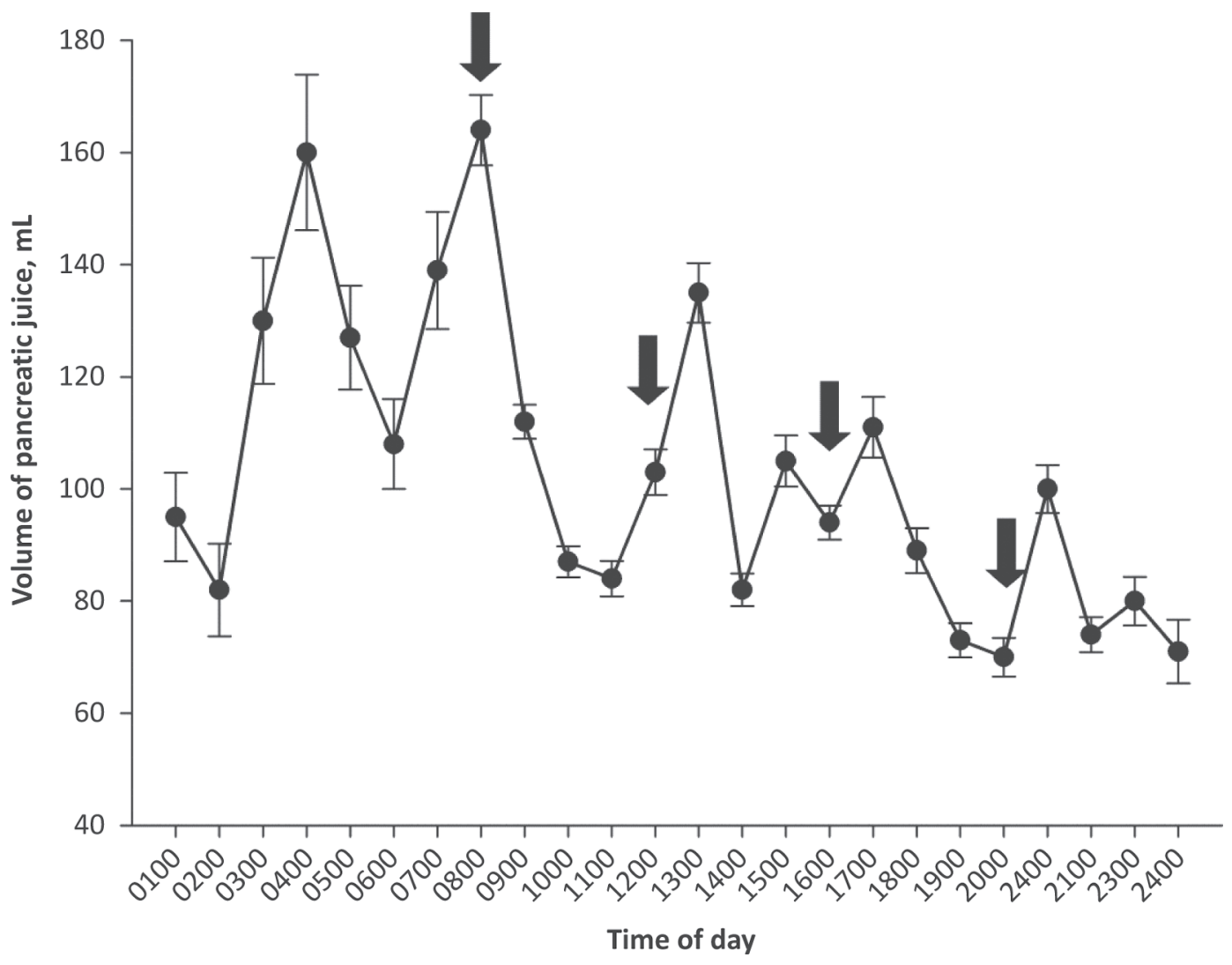

Figure 1. Daily profile of pancreatic fluid flow rate in Holstein heifers in phase 1 . The fluid was collected at hourly intervals for $24 \mathrm{~h}$ for a period of $7 \mathrm{~d}$. Arrows indicate feeding times $(0800,1200,1600$, and $2000 \mathrm{~h}$, respectively). Data are represented as means \pm standard deviations $(\mathrm{n}=4)$. 
Table 4. Effects of duodenal infusion of leucine on secretion rate and activities of $\alpha$-amylase, trypsin, chymotrypsin, and lipase in pancreatic fluid $^{1}$

\begin{tabular}{|c|c|c|c|c|c|c|}
\hline Item & \multicolumn{4}{|c|}{ Leucine infusion, g } & $\mathrm{SEM}^{2}$ & $P$-value \\
\hline \multicolumn{7}{|l|}{$\alpha$-Amylase } \\
\hline $\mathrm{U} / \mathrm{mg}$ of protein & 26.1 & 29.6 & 24.8 & 25.7 & 3.10 & 0.326 \\
\hline $\mathrm{U} / \mathrm{h}$ & $18,714^{\mathrm{c}}$ & $35,261^{\mathrm{a}}$ & $25,380^{\mathrm{b}}$ & $27,990^{\mathrm{b}}$ & $2,985.3$ & 0.007 \\
\hline \multicolumn{7}{|l|}{ Trypsin } \\
\hline \multicolumn{7}{|l|}{ Chymotrypsin } \\
\hline $\mathrm{U} / \mathrm{L}$ & 1,187 & 1,331 & 1,246 & 1,488 & 128.9 & 0.106 \\
\hline $\mathrm{U} / \mathrm{mg}$ of protein & 0.197 & 0.192 & 0.160 & 0.174 & 0.037 & 0.461 \\
\hline $\mathrm{U} / \mathrm{h}$ & $145^{\mathrm{c}}$ & $233^{\mathrm{a}}$ & $163^{\mathrm{c}}$ & $191^{\mathrm{b}}$ & 22.8 & 0.037 \\
\hline \multicolumn{7}{|l|}{ Lipase } \\
\hline $\mathrm{U} / \mathrm{mL}$ & 336 & 368 & 427 & 396 & 40.5 & 0.069 \\
\hline
\end{tabular}

${ }^{\mathrm{a}-\mathrm{c}}$ Means within a row with different superscripts differ $(P \leq 0.05)$.

${ }^{1}$ One unit of enzyme is defined as $1 \mu \mathrm{mol}$ of the product formed per minute at $39^{\circ} \mathrm{C}$.

${ }^{2}$ Pooled standard error of the means, $\mathrm{n}=4$.

6 , or $9 \mathrm{~g} / \mathrm{d}$ of leucine in goats for a period of $10 \mathrm{~h}$ affected secretion of pancreatic fluid in goats with a quadratic dose-response curve, and the greatest value was obtained with $3 \mathrm{~g} / \mathrm{d}$ leucine infusion ( $\mathrm{Yu}$ et al., 2014a). Another study in rats revealed that luminal nutrient signals could change pancreatic secretion by up to $50 \%$ (Li et al., 2000). However, no changes in pancreatic fluid secretion were observed when starch or casein was infused into the abomasum (Richards et al., 2003; Swanson et al., 2004). A direct comparison between species needs to be treated with caution due to the difference in digestive systems between rats and ruminant species. Further research will be required to verity if this increase in pancreatic secretion is from stimulating function of leucine.

In this experiment, protein excretion rate $(\mathrm{mg} / \mathrm{h}$, the product of protein concentration in the fluid with flow rate) was significantly increased by leucine infusion, especially the $10 \mathrm{~g}$ level. The increase of protein concentration was likely attributed to the function of leucine as an anabolic agent that stimulates protein synthesis by modulating the activation of the mTOR pathway and signaling components of translation initiation in various tissues of species (Yin et al., 2010; Suryawan et al., 2011; Wilson et al., 2011). Rulquin and Pisulewski (2006) reported that duodenal infusions of leucine promoted mammary protein output. However, no responses in milk yield and composition have also been reported in cows supplemented with rumen-protected leucine tablets (Krizova et al., 2008). It should be pointed out that the effect of leucine on protein synthesis seems to be tissue specific, and leucine stimulates protein synthesis in muscles and liver, but not in heart, kidney, and jejunum (Wilson et al., 2011). The protein concentration in pancreatic fluid and the flow rate in current experiment ranged from 6.03 to $8.54 \mathrm{mg} / \mathrm{mL}$ and 738 to $1,212 \mathrm{mg} / \mathrm{h}$, respectively, lower than the values in previous reports. For example, Richards et al. (2003) reported protein concentration in pancreatic fluid ranged of 9.65 to $10.87 \mathrm{mg} / \mathrm{mL}$ and the flow rate from 1,414 to $1,645 \mathrm{mg} / \mathrm{h}$. The results from Swanson et al. (2004) were even higher (24.1 to $32.2 \mathrm{mg} / \mathrm{mL}$ and 1,600 to $2,130 \mathrm{mg} / \mathrm{h}$, respectively). One possible reason for the difference between our results and the reported values is the physiological stages of the animals used, and young heifers were used in this experiment. Calves have low pancreatic protein secretion, and the secretion increases with age (McCormick and Stewart, 1967).

Table 5. Effects of duodenal infusion of leucine on plasma glucose and insulin concentrations

\begin{tabular}{|c|c|c|c|c|c|c|}
\hline \multirow[b]{2}{*}{ Item } & \multicolumn{4}{|c|}{ Leucine infusion, $g$} & \multirow[b]{2}{*}{$\mathrm{SEM}^{1}$} & \multirow[b]{2}{*}{$P$-value } \\
\hline & 0 & 10 & 20 & 30 & & \\
\hline Glucose, mmol/L & 3.37 & 3.69 & 3.53 & 3.55 & 0.211 & 0.254 \\
\hline Insulin, pmol/L & 78.4 & 82.9 & 86.1 & 75.3 & 8.46 & 0.091 \\
\hline
\end{tabular}

${ }^{1}$ Pooled standard error of the means, $\mathrm{n}=4$. 
In addition, different nutritional status among various studies may also spare effects on protein secretion in pancreatic fluid.

The increase in dietary concentrations of amino acids could stimulate muscle (Dreyer et al., 2008) and milk (Burgos et al., 2010) protein synthesis, and among amino acids, leucine is the most effective by regulating the mTOR (mammalian target of rapamycin) networks in different organs (Kim, 2009; Vianna et al., 2010), such as the pancreas (Sans et al., 2006).

Walker and Harmon (1995) identified that the lack of $\alpha$-amylase activity may be a major factor limiting the efficiency of starch digestion in the small intestine. This experiment clearly demonstrated leucine infusions significantly increased $\alpha$-amylase activity, including both the concentration and the secretion rate. The results of this experiment are supported by a previous report from this laboratory that the secretion rate of $\alpha$-amylase in goats was increased by infusions of 3 or 6 $\mathrm{g} / \mathrm{d}$ of leucine over a period of $10 \mathrm{~h}$ (Yu et al., 2014a).

Leucine infusions had no effects on the concentrations ( $\mathrm{U} / \mathrm{L}$ or $\mathrm{U} / \mathrm{mL}$ and $\mathrm{U} / \mathrm{mg}$ protein) of trypsin, chymotrypsin, and lipase in the pancreatic fluid, but infusion of $10 \mathrm{~g}$ of leucine increased the secretion rate $(\mathrm{U} / \mathrm{h})$ of all 3 enzymes. The increases in the secretion rate with no significant changes in their concentrations may indicate that infused leucine had more profound effects on stimulation of pancreatic fluid secretion over enhancement of synthesis of these proteins. Amino acids play an essential role in provision of the substrate for the synthesis of all the enzymes. In contrast, Swanson et al. (2003) identified that provision of amino acids alone decreased trypsin release from pancreas tissue of calves in vitro, but supply of amino acids plus casein increased trypsin release. Yu et al. (2014a) reported reductions of the trypsin secretion rate in goats with leucine infused for a period of $10 \mathrm{~h}$, no changes with leucine infused for $14 \mathrm{~d}$, but when leucine was infused for $21 \mathrm{~d}$ the trypsin secretion rate was increased (Yu et al., 2014b). These reports imply that the response of trypsin secretion to leucine appears to be a slow process.

The information about effects of amino acids on activities of chymotrypsin and lipase in ruminants is scarce. Yu et al. (2014a) reported that leucine infusion had no effect on lipase activity in pancreatic fluid of goats (Yu et al., 2014a). One possible explanation for the contradictory effects of leucine on the activities of protease and lipase could be that the dosages of leucine differed in different experiments, which could affect the balance of amino acids and the synthesis of protein in the small intestine. Besides, the ages of animals, the length of infusion period, and the diet composition could also result in variations in outcomes. More studies are required, therefore, to reveal the effects of amino acids on activities of digestive enzymes, particularly proteases, in ruminants.

Our results showed that duodenal infusion of leucine had no significant effect on plasma insulin concentration. Insulin is an important component of pancreatic $\alpha$-amylase regulation in nonruminants (Brannon, 1990), but little information is available on the relationship between insulin and pancreatic $\alpha$-amylase secretion in ruminants. Anthony et al. (2002) found that increases in serum insulin were involved in the leucine-induced stimulation of muscle protein synthesis in young adult rats. Pancreatic enzyme secretion was decreased in diabetic rats, but restored to the normal level when insulin was infused (Otsuki and Williams, 1982), suggesting that insulin plays a role in the regulation of $\alpha$-amylase secretion. Leucine acts as an insulin secretagogue and can increase circulating insulin levels. Swanson et al. (2004) suggested that plasma insulin concentrations might not be related to $\alpha$-amylase secretion. Although the plasma insulin concentration did not mirror the pancreatic secretion of $\alpha$-amylase in this study, it does not rule out roles of insulin in protein synthesis. Insulin plays differential roles in modulating protein synthesis in various tissues in the neonatal pigs (Suryawan et al., 2009). Further studies are needed to evaluate the regulatory mechanisms of leucine, via insulin, on pancreatic enzymes in ruminants.

\section{CONCLUSIONS}

Intestinal supply of leucine enhanced the concentration and secretion of pancreatic $\alpha$-amylase in heifers. Leucine could act as a nutrient signal to stimulate the secretion of $\alpha$-amylase, trypsin, chymotrypsin, and lipase, and the responses appeared to be dose and time dependent. Defining specific mechanisms through which leucine regulates secretion of $\alpha$-amylase could lead to the development of applicable means to increase $\alpha$-amylase secretion for starch digestion in small intestines.

\section{ACKNOWLEDGMENTS}

This research was funded by the National Funds for Natural Science of P. R. China (31472122), the National Key Technologies R\&D Program of China (2012BAD12B02), and the Program of International S\&T Cooperation of China (2010DFB34230).

\section{REFERENCES}

Anthony, J. C., A. K. Reiter, T. G. Anthony, S. J. Crozier, C. H. Lang, D. A. MacLean, S. R. Kimball, and L. S. Jefferson. 2002. Orally administered leucine enhances protein synthesis in skeletal muscle 
of diabetic rats in the absence of increases in 4EBP1 or S6K1 phosphorylation. Diabetes 51:928-936.

Brannon, P. 1990. Adaptation of the exocrine pancreas to diet. Annu. Rev. Nutr. 10:85-105.

Burgos, S. A., M. Dai, and J. P. Cant. 2010. Nutrient availability and lactogenic hormones regulate mammary protein synthesis through the mammalian target of rapamycin signaling pathway. J. Dairy Sci. 93:153-161.

Dreyer, H. C., M. J. Drummond, B. Pennings, S. Fujita, E. L. Glynn, D. L. Chinkes, S. Dhanani, E. Volpi, and B. B. Rasmussen. 2008. Leucine-enriched essential amino acid and carbohydrate ingestion following resistance exercise enhances mTOR signaling and protein synthesis in human muscle. Am J. Physiol. Endocrinol. Metab. 294:E392-E400.

Escobar, J., J. W. Frank, A. Suryawan, H. V. Nguyen, S. R. Kimball, L. S. Jefferson, and T. A. Davis. 2005. Physiological rise in plasma leucine stimulates muscle protein synthesis in neonatal pigs by enhancing translation initiation factor activation. Am. J. Physiol. Endocrinol. Metab. 288: 914-921.

Geiger, R., and H. Fritz. 1986. Trypsin. Pages 119-128 in Methods of Enzymatic Analysis. Vol. 5. H. Bergmeyer, ed. Academic Press, New York, NY.

Gressley, T. F., M. B. Hall, and L. Armentano. 2011. Ruminant Nutrition Symposium: Productivity, digestion, and health responses to hindgut acidosis in ruminants. J. Anim. Sci. 89:1120-1130.

Harmon, D. L., K. Yamada, and N. A. Elam. 2004. Factors affecting intestinal starch digestion in ruminants: A review. Can. J. Anim. Sci. 84:309-318.

Hashimoto, N., and H. Hara. 2004. Dietary branched-chain amino acids suppress the expression of pancreatic amylase mRNA in rats. Biosci. Biotechnol. Biochem. 68:1067-1072.

Kim, E. 2009. Mechanisms of amino acid sensing in mTOR signaling pathway. Nutr. Res. Pract. 3:64-71.

Krizova, L., J. Trinacty, M. Richter, S. Hadrov, and J. Pozdisek. 2008. Effect of ruminally-protected leucine supplement on milk yield and plasma amino acids in dairy cows. Agric. Food. Sci. 17:351-359.

Li, Y., Y. Hao, J. Zhu, and C. Owyang. 2000. Serotonin released from intestinal enterochromaffin cells mediates luminal noncholecystokinin-stimulated pancreatic secretion in rats. Gastroenterology 118:1197-1207.

Matthé, A., P. Lebzien, I. Hric, G. Flachowsky, and A. Sommer. 2001. Effect of starch application into the proximal duodenum of ruminants on starch digestibility in the small and total intestine. Arch. Tierernahr. 55:351-369.

McCormick, R. J., and W. Stewart. 1967. Pancreatic secretion in the bovine calf. J. Dairy Sci. 50:568-571.

NRC. 1996. Nutrient Requirements of Beef Cattle. 7th ed. National Acad. Press, Washington, DC.

Otsuki, M., and J. A. Williams. 1982. Effect of diabetes mellitus on the regulation of enzyme secretion by isolated rat pancreatic acini. J. Clin. Invest. 70:148-156.

Proud, C. 2007. Signalling to translation: How signal transduction pathways control the protein synthetic machinery. Biochem. J. 403:217-234.

Reynolds, C. K. 2006. Production and metabolic effects of site of starch digestion in dairy cattle. Anim. Feed Sci. Technol. 130:78-94.

Richards, C. J., K. C. Swanson, S. J. Paton, D. L. Harmon, and G. B. Huntington. 2003. Pancreatic exocrine secretion in steers infused postruminally with casein and cornstarch. J. Anim. Sci. 81:1051-1056.

Rulquin, H., and P. M. Pisulewski. 2006. Effects of graded levels of duodenal infusions of leucine on mammary uptake and output in lactating dairy cows. J. Dairy Res. 73:328-339.

Sans, M. D., M. Tashiro, N. L. Vogel, S. R. Kimball, L. G. D'Alecy, and J. A. Williams. 2006. Leucine activates pancreatic translational machinery in rats and mice through mTOR independently of CCK and insulin. J. Nutr. 136:1792-1799.
Shimomura, Y., T. Murakami, N. Nakai, M. Nagasaki, and R. A. Harris. 2004. Exercise promotes BCAA catabolism: Effects of BCAA supplementation on skeletal muscle during exercise. J. Nutr. 134:1583S-1587S.

Shimomura, Y., Y. Yamamoto, G. Bajotto, J. Sato, T. Murakami, N. Shimomura, H. Kobayashi, and K. Mawatari. 2006. Nutraceutical effects of branched-chain amino acids on skeletal muscle. J. Nutr. 136:529S-532S.

Smith, P., R. I. Krohn, G. T. Hermanson, A. K. Mallia, F. H. Gartner, M. D. Provenzano, E. K. Fujimoto, N. M. Goeke, B. J. Olson, and D. C. Klenk. 1985. Measurement of protein using bicinchoninic acid. Anal. Biochem. 150:76-85.

St-Jean, G., D. Harmon, J. Peters, and N. Ames. 1992. Collection of pancreatic exocrine secretions by formation of a duodenal pouch in cattle. Am. J. Vet. Res. 53:2377-2380.

Suryawan, A., P. M. O'Connor, J. A. Bush, H. V. Nguyen, and T. A. Davis. 2009. Differential regulation of protein synthesis by amino acids and insulin in peripheral and visceral tissues of neonatal pigs. Amino Acids 37:97-104.

SuryawanA.OrellanaR. A.FiorottoM. L.DavisT. A. 2011. Triennial Growth Symposium: Leucine acts as a nutrient signal to stimulate protein synthesis in neonatal pigs. J. Anim. Sci. 89:2004-2016.

Swanson, K., J. Benson, J. Matthews, and D. Harmon. 2004. Pancreatic exocrine secretion and plasma concentration of some gastrointestinal hormones in response to abomasal infusion of starch hydrolyzate and/or casein. J. Anim. Sci. 82:1781-1787.

Swanson, K. C., J. C. Matthews, C. A. Wood, and D. L. Harmon. 2003. Influence of substrate and/or neurohormonal mimic on in vitro pancreatic enzyme release from calves postruminally infused with partially hydrolyzed starch and/or casein. J. Anim. Sci 81:1323-1331.

Swanson, K. C., C. J. Richards, and D. L. Harmon. 2002. Influence of abomasal infusion of glucose or partially hydrolyzed starch on pancreatic exocrine secretion in beef steers. J. Anim. Sci. 80:11121116.

Vianna, D., G. F. R. Teodoro, F. L. Torres-Leal, and J. Tirapegui 2010. Protein synthesis regulation by leucine. Braz. J. Pharm. Sci. 46:29-36.

Walker, J. A., and D. L. Harmon. 1995. Influence of ruminal or abomasal starch hydrolysate infusion on pancreatic exocrine secretion and blood glucose and insulin concentrations in steers. J. Anim. Sci. 73:3766-3774.

Wilson, F. A., F. A. Wilson, A. Suryawan, R. A. Orellana, M. C. Gazzaneo, H. V. Nguyen, and T. A. Davis. 2011. Differential effects of long-term leucine infusion on tissue protein synthesis in neonatal pigs. Amino Acids 40:157-165.

Xu, M., S. Du, J. Wang, Z. P. Yu, D. L. Harmon, and J. H. Yao. 2009. Influence of rumen escape starch on pancreatic exocrine secretion of goats. J. Anim. Physiol. Anim. Nutr. (Berl.) 93:122-129.

Xu, M., J. Yao, Y. Wang, and F. Wang. 2006. Influence of rumen escape starch on $\alpha$-amylase activity in pancreatic tissue and small intestinal digesta of lambs. Asian-australas. J. Anim. Sci. 19:1749-1754.

Yin, Y. L., K. Yao, Z. J. Liu, M. Gong, Z. Ruan, D. Deng, B. Tan, Z. Q. Liu, and G. Y. Wu. 2010. Supplementing L-leucine to a lowprotein diet increases tissue protein synthesis in weanling pigs. Amino Acids 39:1477-1486.

Yu, Z. P., M. Xu, K. Liu, J. H. Yao, H. M. Yu, and F. Wang. 2014a. Leucine markedly regulates pancreatic exocrine secretion in goats. J. Anim. Physiol. Anim. Nutr. (Berl.) 98:169-177.

Yu, Z. P., M. Xu, F. Wang, K. Liu, J. H. Yao, Z. Wu, D. K. Qin, and F. F. Sun. 2014b. Effect of duodenal infusion of leucine and phenylalanine on intestinal enzyme activities and starch digestibility in goats. J. Livest. Sci. 162:134-140. 